\title{
Feasibility and Possibility of Transplanted Pigeonpea (Cajanus cajan L.) under Different Spacing and Nutrient Management Practices
}

\author{
Sweta Shikta Mahapatra ${ }^{1 *}$, Chandra Bhushan ${ }^{1}$, Anil Shukla ${ }^{1}$, \\ V. K. Singh ${ }^{1}$ and Navneet Pareek $^{2}$ \\ ${ }^{1}$ Department of Agronomy, ${ }^{2}$ Department of Soil Science, GBPUAT, Pantnagar, India \\ *Corresponding author
}

\begin{abstract}
A B S T R A C T
Keywords

System of pigeonpea intensification, Transplanting, Vermicompost, Integrated Nutrient Management

Article Info

Accepted:

22 November 2020 Available Online:

10 December 2020

A field experiment was conducted during Kharif seasons of 2018-19 and 2019-20 at N. E. Borlaug Crop Research Centre of Govind Ballabh Pant University of Agriculture \& Technology, Pantnagar (Uttarakhand). The experiment was laid out in Split Plot Design with three replications having four planting methods as the main plot treatments viz; Conventional Sowing at $60 \times 20 \mathrm{~cm}$, Transplanting at $60 \times 20 \mathrm{~cm}, 90 \times 40 \mathrm{~cm}$ and $90 \times 60$ $\mathrm{cm}$, and three nutrient management practices as Sub plot treatments viz; $100 \% \mathrm{RDF}$ (12:32:16 NPK fertilizer @ $\left.150 \mathrm{~kg} \mathrm{ha}^{-1}\right)$, Vermicompost at 5 ton $\mathrm{ha}^{-1}$ and $50 \% \mathrm{RDF}+$ Vermicompost at 2.5 ton $^{-1}{ }^{-1}$. The test variety of used was 'Pant Arhar 291'. The growth, yield, soil quality and economics of pigeonpea crop were found to be significantly influenced by various planting methods and nutrient management practices. Transplanting at $90 \times 40 \mathrm{~cm}$ recorded the highest grain yield during both the years due to relatively higher plant population per unit area. The grain yield was 32.6 and $34.7 \%$ higher over that of the Conventional Sowing at $60 \times 20 \mathrm{~cm}$ during 2018-19 and 2019-20, respectively. The combination of inorganic and organic sources led to significantly better microbial population along during both the years. The maximum gross returns were obtained in case of Transplanting at $90 \times 40 \mathrm{~cm}$ spacing. Among the nutrient management practices, the gross returns were highest with $50 \% \mathrm{RDF}+$ Vermicompost at 2.5 ton $\mathrm{ha}^{-1}$. Thus for sustained productivity of pigeon pea, it can be transplanted at $90 \times 40 \mathrm{~cm}$ spacing and for nutrient application integration of $50 \% \mathrm{RDF}+$ Vermicompost at 2.5 ton ha $^{-1}$ could be taken as the most promising practices for System of Pigeonpea Intensification.
\end{abstract}

\section{Introduction}

Since ancient time, pulses are a fundamental component of the global cropping system after cereals and oilseeds particularly in the Indian context. The dal which is a necessary constituent of human diets in India is actually the pulse grains in the form of splits as a rich protein resource (pulses protein content 20 $30 \%$ ). A dietary mixture of cereals and pulses together provides an advanced biological value, than their sole consumption. The global pulse production accounts for 61.5 million ton expanding over an area of 70.6 million hectare with an average productivity of 806 $\mathrm{kg} \mathrm{ha}^{-1}$. India has a total area of 29 million 
hectares under pulses, which accounts to a production of 25.2 million tones, having an average productivity of $841 \mathrm{~kg} \mathrm{ha}^{-1}$ (Ministry of Agri \& FW, 2018).

Pigeonpea [Cajanus cajan (L.) Millsp.] also known as arhar, tur, redgram, congopea, no eye pea etc., is a pre-dominant pulse crop in India. It is a perennial short lived multipurpose shrub legume, belonging to leguminaceae family cultivated as an annual crop across the world in both tropical as well as sub-tropical regions. The nutritive profile of pigeon pea is; 55.7, 21.0, 5.1, 2.3 and 8.2\% carbohydrate, protein, soluble sugar, fat \& mineral and crude fibre, respectively. The protein digestibility of pigeon pea is also high accounting for about 66.8 percent (Saxena, 2010). The pigeon pea is the second most important pulse crop in India after chickpea in terms of area and production, cultivated over an area of 4.43 million hectares with production accounting to 4.25 million tonnes, having average productivity of $937 \mathrm{~kg} \mathrm{ha}^{-1}$ (Ministry of Agri \& FW, 2018). However, the overall productivity of pigeonpea has remained between 637 to $813 \mathrm{~kg} \mathrm{ha}^{-1}$ for last several decades (Agriculture statistics at a glance, 2015). Being a deep rooted crop it acts as a "Biological plough".

The present productivity of pegionpea is quite low and largely owing to abiotic stresses related to soil moisture content and fertility. The growth and development of any crop is influenced by availability of different growth factors i.e., light, temperature, moisture and nutrient availability. The production, accumulation and translocation of the metabolites from source to sink is primarily the product of its genetics and available environment, whose efficiency is enhanced by adopting proper agronomic management, thereby harnessing the various resources in order to achieve higher production. The main agronomic manipulations affecting the crop development and yield are- timely sowing or planting, competent planting methods, maintenance of optimum plant population and planting geometry (Chaudhary and Thakur, 2005). The yield in pigeonpea is an integrated output of different yield attributing characters and plant population, which is in turn manipulated by planting geometry. Yield improvement can alternatively be achieved by reducing external input dependence rather focusing on mobilizing the biological processes and potentials that are available in existing plant and soil systems.

A great hope for improving the productivity of Pigeonpea has been witnessed in the concept System of Pigeon pea Intensification (SPI), which can help to combat the climatic aberrations experienced by the crop (Praharaj et al., 2015). The concept of SPI deals with maximization of yield and net return per unit area of pigeonpea through adoption of a low input-intensive technology. This depends on external inputs to a minimum extent rather induces larger, better-functioning root systems helping in better resource utilization and mobilization towards yield. This system has a number of advantages; including need for less number of seeds for sowing, less need of water and nutrients, ease in sowing by manual dibbling through poly bags etc. This technique has been found quite stable under both abiotic and biotic stresses. For harnessing the potential of a crop like pigeon pea (having branching habit), planting at proper spacing is a pre-requisite to make best use of the available resources.

The optimum spacing depends upon the nature of variety, soil type and prevailing climatic conditions. Sujatha (2017) found transplanting of pigeonpea at $120 \times 30 \mathrm{~cm}$ as the most optimum spacing for rainfed situations. Sajjan (2018) found 120 x $30 \mathrm{~cm}$ and $90 \times 30 \mathrm{~cm}$ as the optimum spacing for transplanting of pigeonpea at Vijayapur, 
Dharwad, Karnataka. In present day agriculture, rampant use of inorganic with minimum or no organic manure, the cultivable lands are depleted in organic C content and becoming unfertile and exerting multiple nutrient deficiencies. Despite the gains of the green revolution for achieving self sufficiency in food grain production, intensive cropping practices coupled with extensive chemical inputs usage made an adverse impact on natural resource base leading to a decline in crop productivity as well as food quality. At this juncture, there is a need device a nutrient management practice that can last for long without affecting the soil and environmental health. Balanced fertilization is necessary to increase the productivity of Pigeon pea. The NPK uptake of pigeon pea crop accounts to about $63.3 \mathrm{~kg}$ $\mathrm{N}, 15.8 \mathrm{~kg} \mathrm{P}_{2} \mathrm{O}_{5}$ and $49.8 \mathrm{~kg} \mathrm{~K}_{2} \mathrm{O}$ (Tamboli et al., 1995). Proper nutrient management of pigeon pea provides a great scope for enhancing yield and productivity by making up for the crop nutrient demand. By Balanced nutrient management not only we can adequately meet up the crop requirement but also prevent soil degradation by reducing the leaching losses helping in improving the nutrient availability and use efficiency.

Integrating inorganic, organic and biofertilizers are essential in realizing the higher pigeonpea yield and reducing cost of production has been reported by Reddy et al., (2011). The work of various research workers indicated that integrated nutrient management practice may play significant role to promote growth and productivity of pigeonpea in a sustainable basis as well as soil health.Vermicompost is a brilliant source for this purpose as it not only improvises the yields but also causes a substantial improvement in soil microbiological community development by providing organic matter along with various growth promoting enhancers supporting their growth and development. The vermicompost contains several growth enhancing hormones i.e., auxins, cytokinins and gibberlins along with metabolites, vitamins viz., Vitamin $\mathrm{D}$ and $\mathrm{B}$ and micro elements which directly promote plant growth. Other than having inherent higher content of $\mathrm{N}, \mathrm{P}, \mathrm{K}, \mathrm{Ca}$ and $\mathrm{Mg}$ they amend the soil structure helping in release of fixed $\mathrm{Ca}, \mathrm{Mg}$ and several micronutrients (Orozzo et al., 1996). The population of microorganisms in vermicompost is higher than traditional composts and the type of microbes found depends on the types of earthworm species used for composting. The common growth enhancing microbes found are as follows, Pseudomonas oxalaticus, Rhizobium japonicum, Oseudomonas putida, NPK availability enhancers viz., Azospirillum sp., Azotobacter sp., Nitrosomonas sp., Nitrobacter sp. and phosphate solubulisers (Gopal et al., 2009; Pathama and Sakthivel, 2012). Somashekar (2017) suggested that application of Vermicompost @ $5 \mathrm{t} \mathrm{ha}^{-1}$ in Pigeon pea crop at Raipur, Chattishgarh over farmer's practice of application of $100 \%$ RDF.

\section{Materials and Methods}

A field experiment was conducted during Kharif seasons of 2018-19 and 2019-20 at N. E. Borlaug Crop Research Centre of Govind Ballabh Pant University of Agriculture \& Technology, Pantnagar (Uttarakhand). The experiment was laid out in Split Plot Design with three replications having four planting methods as the main plot treatments viz; Conventional Sowing at $60 \mathrm{x} 20 \mathrm{~cm}$, Transplanting at $60 \times 20 \mathrm{~cm}, 90 \times 40 \mathrm{~cm}$ and $90 \times 60 \mathrm{~cm}$, and three nutrient management practices as Sub plot treatments viz; $100 \%$ RDF (12:32:16 NPK fertilizer @ $150 \mathrm{~kg} \mathrm{ha}^{-1}$ ), Vermicompost at 5 ton $\mathrm{ha}^{-1}$ and $50 \% \mathrm{RDF}+$ Vermicompost at 2.5 ton $\mathrm{ha}^{-1}$. The soil of the experimental site was silty clay loam in texture being low in available nitrogen (256.2 
and $261.5 \mathrm{~kg} / \mathrm{ha}$ ), high in available phosphorus (26.1 and $25.3 \mathrm{~kg} / \mathrm{ha}$ ), low in available potassium (149.6 and $153.3 \mathrm{~kg} / \mathrm{ha}$ ), and high in organic carbon (0.80 and $0.87 \%)$ with a neutral soil reaction $(\mathrm{pH} 7.24$ and 7.49) during the two years of study.The test variety of pigeonpea used was 'Pant Arhar 291'. Seeds treated with thiram @ $2 \mathrm{~g}+$ carbendazim@1 g/kg seed for protection against soil borne diseases. Seeds were inoculated with Rhizobium and PSB @ $20 \mathrm{~g}$ of each per $\mathrm{kg}$ of seeds to enhance nodulation and phosphorous use efficiency. The conventional crop was sown by line placement of seeds manually where as the nursery for the transplanted crop was sown on the same date. The 21 day old seedlings were transplanted in the field on the third week of June with onset of monsoon according to treatments. The furrows were prepared at spacings of $60 \times 20 \mathrm{~cm}, 90 \times 40 \mathrm{~cm}$ and $90 \times$ $60 \mathrm{~cm}$ as per the treatment layout with furrow opener. One healthy seedling per hill was placed as per the inter row spacing according to the main plot treatment in furrows and later raised beds were made with Phaura. Initally use of auger was done to make holes on raised beds at required spacing for one plot but as it required more labour and time the above mentioned alternate method was preferred. One hand weeding and 1 mild irrigation after sowing and transplanting were undertaken during the entire crop period. One spray of pendimethalin @1ml/L was also taken up. One spray of each, monocrotophos 36 SL @ $1 \mathrm{ml} / \mathrm{L}$ and Indoxacarb @ $1.5 \mathrm{ml} / \mathrm{L}$ was also done. When the plants turned yellow and the pods to brown colour, the crop from border rows and net plots were harvested separately. The pods of each treatment were sun dried thoroughly and threshed manually. Then the seeds were dried and cleaned. The stalk from each net plot was harvested and sun dried.

The climate of the region is broadly humid sub-tropical with harsh winters and hot dry summers. During hot summer, the maximum temperature exceeds $40^{\circ} \mathrm{C}$, while in winter the minimum temperature occasionally touches $1^{\circ} \mathrm{C}$. The monsoon usually starts in the third week of June and continues till the middle of September at Pantnagar. Frost is expected from late December to February. The mean relative humidity remains almost $80-90$ per cent from mid-June to end of February and then it steadily decreases to 50 per cent by the first week of May and remains same till mid June. Weather parameters prevailing during the crop season were obtained from the meteorological observatory located in the N.E. Borlaug Crop Research Centre of the university which is presented in Table 1 and 2 for the Kharif season 2018-19 and 2019-20, respectively.

A recommended dose of $150 \mathrm{~kg} \mathrm{ha}^{-1}$ for $100 \%$ RDF was applied through NPK mix as per treatment as basal at the time of sowing. The site specific vermicompost application and incorporated on per plant basis at the time of transplanting. The details of amount of nutrient supplied through applied rate are given in Table 3 . The content of $\mathrm{N}: \mathrm{P}_{2} \mathrm{O}_{5}$ : $\mathrm{K}_{2} \mathrm{O}(\%)$ is $12: 32: 16$ in NPK mix and 1.91: 1.18: 1.51 , respectively.

The observations were taken using destructive and non-destructive sampling methods. Five plants in each net plot were selected and tagged in each treatment for recording periodical observations on growth parameters at 30 days interval and yield attributes at harvest. For recording leaf area and dry matter production, destructive sampling was done by taking 3 plants each time from the border rows. The data recorded on various parameters of crop during the course of investigation was statistically analyzed following the analysis of variance for randomized block design as suggested by Kwanchai A. Gomez and Arturo A. Gomez (1983). Statistical significance was tested 
with ' $F$ ' value at $5 \%$ level of probability. Critical Difference (CD) for the significant sources of variation was calculated at $5 \%$ level of significance.

\section{Results and Discussion}

The growth, soil microbial population, yield and gross returns of pigeonpea crop were found to be significantly influenced by various planting methods and nutrient management practices (Fig. 1 and Table 1-6).

\section{Effect on Plant height and leaf area}

At 30 DAS, Conventional sowing at $60 \times 20$ $\mathrm{cm}\left(\mathrm{C}_{1}\right)$ treatment resulted in plants of tallest stature in both the years $(36.7 \& 40.7 \mathrm{~cm})$. This was followed by Transplanting at $60 \mathrm{x}$ $20 \mathrm{~cm}\left(\mathrm{~T}_{1}\right)(30.4 \& 32.9 \mathrm{~cm})$, Transplanting at $90 \mathrm{x} 40 \mathrm{~cm}\left(\mathrm{~T}_{2}\right) \quad(30.2 \& 32.7 \mathrm{~cm})$ and Transplanting at $90 \times 60 \mathrm{~cm}\left(\mathrm{~T}_{3}\right)(30.1 \& 32.6$ $\mathrm{cm})$, which were also statistically at par with each other in 2018-2019. But at 60 DAS the highest plant height of pigeonpea was registered with Transplanting at $60 \times 20 \mathrm{~cm}$ $\left(\mathrm{T}_{1}\right)$, which was comparable with the next better treatment Transplanting at $90 \times 40 \mathrm{~cm}$ $\left(\mathrm{T}_{2}\right)$ in 2018. Transplanting at $90 \times 60 \mathrm{~cm}\left(\mathrm{~T}_{3}\right)$ and Conventional sowing at $60 \times 20 \mathrm{~cm}\left(\mathrm{C}_{1}\right)$ recorded the lowest plant height and were also found to be at par with each other in 2018. The results were also same in 2019. Similar findings were also recorded by Panda (2017), Sujatha (2017) and Somashekar (2017). The plant height of pigeonpea was not influenced significantly by nutrient management practices at 30 DAS, in both 2018 and 2019. At later stages of growth i.e. 60 DAS the plants of tallest stature were recorded under $50 \% \mathrm{RDF}+$ Vermicompost at 2.5 ton ha ${ }^{1}\left(\mathrm{~N}_{3}\right)$ which was followed by Vermicompost at 5 ton $\mathrm{ha}^{-1}\left(\mathrm{~N}_{2}\right)$ and was on par with the same. The plants of lowest stature were recorded by $100 \%$ RDF (18: 48: $24 \mathrm{~kg} \mathrm{~N}$ : $\mathrm{P}_{2} \mathrm{O}_{5}: \mathrm{K}_{2} \mathrm{O}$ ha $\left.^{-1}\right)\left(\mathrm{N}_{2}\right)$ which were at par statistically with the later. At 30 DAS, Conventional planting system recorded significantly highest leaf area per plant. Among treatments leaf area per plant didn't vary significantly during both the years. At 60 days of recording transplanted pigeon-pea at $90 \times 60 \mathrm{~cm}$ recorded significantly higher leaf area per plant as compared to other planting systems during both the years. It was followed by Transplanting at $90 \times 40 \mathrm{~cm}$ with a significant reduction as compared to the previous treatment. Further, Transplanting at $60 \times 20 \mathrm{~cm}$ and conventional sowing at $60 \times 20$ $\mathrm{cm}$ didn't show any significant differences in leaf area per plant. However, both were found to be significantly inferior as compared to transplanting at $90 \times 40 \mathrm{~cm}$ at all the stages in both the years.

The leaf area per plant was also affected significantly by nutrient management practices at all the stages. The treatment $50 \%$ $\mathrm{RDF}+$ Vermicompost at 2.5 ton $\mathrm{ha}^{-1}\left(\mathrm{~N}_{3}\right)$ registered the maximum value and was followed by Vermicompost at 5 ton $\mathrm{ha}^{-1}\left(\mathrm{~N}_{2}\right)$, which in turn remained on par with each other. Further leaf area per plant observed in VC alone didn't differ significantly with application of $100 \%$ RDF.

Transplanting of 21 day old seedling helped in better establishment of the crop further the wider spacings might have reduced the competition for space, light and nutrients due to reduced plant population leading to a more vibrant luxurious growth in terms of leaf number and size. Further in close spaced transplanted crops there is higher competition for nutrients which leads to greater upright growth producing a higher plant height whereas, in wider spacings there is lesser competition leading to more lateral growth than upright development thus resulting in lesser plant height. Salakinkoppa and Patil (2010), Pavan et al., (2011), Goud and Andhalkar (2012), Praharaj et al., (2015), 
Mohanadas (2016), Panda (2017) and Sujatha (2017) also reported similar results. The rapid release increases availability of nutrients particularly nitrogen, an important constituent of protoplasm, due to presence of $50 \% \mathrm{RDF}$ leads to amplified auxin and cytokinin availability which are the main contributors for cell division, multiplication and elongation.

The higher metabolic activity owing to presence of both growth promoting hormones and nutrients in vermicompost might be another contributing factor. The results are in accordance with Gholve et al., (2005), Kumawat et al., (2013), Mallikarjun (2012), Hajari et al., (2015), Pal et al., (2016) and Somasekhar (2017).

\section{Effect on days to 50 per cent flowering and days to maturity}

Days to 50 per cent flowering and days to maturity of pigeonpea were significantly influenced by various planting methods and nutrient management practices. The transplanted systems took significantly greater time to obtain $50 \%$ flowering and were on average higher by 7 days in comparison to conventional planting system during both the years. The transplanting at 60 x $20 \mathrm{~cm}$ took the highest time to reach $50 \%$ flowering, followed by transplanting at $90 \mathrm{x}$ $40 \mathrm{~cm}$ and $90 \times 60 \mathrm{~cm}$. All three of the treatments were statistically at par. The conventional planting method at $60 \times 20 \mathrm{~cm}$ took the significantly lowest number of days to reach 50\% flowering in both 2018 and 2019. Among the nutrient management practices, the application of VC alone @ 5 t/ha took the highest number of days to reach flowering. This was followed by $50 \% \mathrm{RDF}+$ VC@ 2.5 t/ha and 100\% RDF which were on par with each other in both the years. The transplanted crop matured later by 9-15 days than the conventional planting system crop. There was a significant difference observed during both 2018 and 2019. The transplanting at $60 \times 20 \mathrm{~cm}$ took the highest time to reach maturity and was at par with transplanting at $90 \times 40 \mathrm{~cm}$. The transplanting at $90 \times 60 \mathrm{~cm}$ took significantly lesser time than these previous treatments but was higher than the conventional sowing at $60 \times 20 \mathrm{~cm}$. The conventional sowing at $60 \times 20$ reached maturity earliest of all treatments and was significant to all in both the years. The 50\% $\mathrm{RDF}+\mathrm{VC} @ 2.5 \mathrm{t} / \mathrm{ha}$ was at par with 100\% RDF statistically. Those were followed by VC @ 5 t/ha which matured earliest and took significantly lowest time in 2018 and 2019.

The transplanted pigeonpea had higher growth has a longer vegetative and reproductive period than that of conventional crop. Further the availability of nitrogen and plant growth promoting hormones might have further caused a boost in the vegetative growth therby delaying the flowering and maturity too. The results can be corroborated with the findings of Jamadar et al., (2014), Sajjan (2018), Mallikarjun (2012).

\section{Effect on microbial population}

The population of bacteria, fungi and actinomycetes were highest for transplanting at $90 \times 60 \mathrm{~cm}$ and $90 \times 40 \mathrm{~cm}$ which didn't vary significantly from each other in 2018 and 2019. The populations recorded in transplanting at $60 \times 20 \mathrm{~cm}$ have significantly higher values than conventional sowing at 60 x $20 \mathrm{~cm}$, but was on par with $90 \mathrm{x} 40 \mathrm{~cm}$. The microbial population in conventional planting systems in general reduced significantly than transplanting systems in both the years. The various nutrient management practices showed a significant variation between each other in 2018 and 2019. The 50\% RDF + VC @ 2.5 t/ha was at par with VC @5 t/ha statistically and recorded significantly higher values than $100 \%$ RDF application during both the years. 
Table.1 Standard Meteorological Week' average weather data from May, 2018 to November, 2018 recorded at G. B. Pant University of Agriculture and Technology

\begin{tabular}{|c|c|c|c|c|c|c|c|c|c|c|c|c|}
\hline \multirow[t]{3}{*}{ Month } & \multirow[t]{3}{*}{ Date } & \multirow[t]{3}{*}{ Year } & \multirow{3}{*}{$\begin{array}{c}\text { Metero } \\
\text { Week } \\
\text { No. } \\
(\mathbf{2 0 1 8})\end{array}$} & \multicolumn{2}{|c|}{ Temperature $\left({ }^{\circ} \mathrm{C}\right)$} & \multirow{2}{*}{\multicolumn{2}{|c|}{$\begin{array}{c}\text { Relative humidity } \\
(\%)\end{array}$}} & \multirow{3}{*}{$\begin{array}{c}\text { Rainfall } \\
(\mathbf{m m})\end{array}$} & \multirow{3}{*}{$\begin{array}{c}\text { Number } \\
\text { of rainy } \\
\text { days }\end{array}$} & \multirow{3}{*}{$\begin{array}{c}\text { Sunshine } \\
\left(\text { hours day }^{-1}\right)\end{array}$} & \multirow{3}{*}{$\begin{array}{c}\text { Wind } \\
\text { Velocity } \\
\left(\mathbf{K m ~ h r}^{-1}\right)\end{array}$} & \multirow{3}{*}{$\begin{array}{l}\text { Evaporation } \\
\left(\mathrm{mm} \mathrm{day}^{-1}\right)\end{array}$} \\
\hline & & & & \multirow[t]{2}{*}{ Maximum } & \multirow{2}{*}{ Minimum } & & & & & & & \\
\hline & & & & & & 712 am & $\begin{array}{c}1412 \\
\text { pm }\end{array}$ & & & & & \\
\hline May-Jun & '28-03 & 2018 & 22 & 35.5 & 23.0 & 69.7 & 55.4 & 38.4 & 3 & 7.1 & 9.6 & 8.3 \\
\hline Jun & '04-10 & 2018 & 23 & 35.1 & 26.0 & 82.1 & 63.7 & 87.6 & 2 & 7.7 & 7.5 & 8 \\
\hline Jun & '11-17 & 2018 & 24 & 34.6 & 26.2 & 84.9 & 63.1 & 42.8 & 2 & 5.2 & 5 & 5.7 \\
\hline Jun & ' $18-24$ & 2018 & 25 & 37.2 & 26.1 & 76.4 & 44.7 & 0 & 0 & 7.9 & 6 & 6.8 \\
\hline Jun-Jul & '25-01 & 2018 & 26 & 35.9 & 26.6 & 80.7 & 67.7 & 18.2 & 1 & 6.4 & 7.5 & 7.3 \\
\hline Jul & '02-08 & 2018 & 27 & 32.6 & 25.4 & 90.0 & 70.0 & 18.0 .8 & 3 & 6 & 3.5 & 5.6 \\
\hline Jul & '09-15 & 2018 & 28 & 32.5 & 26.0 & 88.0 & 78.4 & 173.2 & 3 & 3.1 & 6.1 & 4.2 \\
\hline Jul & ' $16-22$ & 2018 & 29 & 33.3 & 26.9 & 82.1 & 73.1 & 79.6 & 2 & 6.7 & 3.7 & 6.6 \\
\hline Jul & '23-29 & 2018 & 30 & 31.2 & 25.7 & 91.0 & 80.0 & 169 & 4 & 2.2 & 5.6 & 4.6 \\
\hline Jul-Aug & ' $30-05$ & 2018 & 31 & 29.7 & 24.1 & 93.6 & 84.0 & 218.1 & 6 & 1 & 2.2 & 3.5 \\
\hline Aug & '06-12 & 2018 & 32 & 30.9 & 24.9 & 90.4 & 79.7 & 126.4 & 3 & 3.6 & 2.6 & 4.3 \\
\hline Aug & '13-19 & 2018 & 33 & 31.9 & 26.1 & 89.0 & 71.7 & 73.4 & 1 & 4 & 1.5 & 3.3 \\
\hline Aug & '20-26 & 2018 & 34 & 30.9 & 25.5 & 95.1 & 83.0 & 160.8 & 5 & 3.2 & 1.1 & 4.4 \\
\hline Aug-Sep & '27-02 & 2018 & 35 & 30.7 & 25.5 & 92.4 & 81.0 & 86.8 & 3 & 2 & 3.3 & 2.7 \\
\hline Sep & '03-09 & 2018 & 36 & 32.3 & 25.3 & 90.4 & 76.3 & 76.6 & 2 & 4.7 & 5.3 & 3.9 \\
\hline Sep & ' $10-16$ & 2018 & 37 & 31.9 & 24.3 & 93.0 & 77.6 & 15.6 & 2 & 5.6 & 6.1 & 3.9 \\
\hline Sep & ' $17-23$ & 2018 & 38 & 32.1 & 22.6 & 90.1 & 73.4 & 49.2 & 1 & 6.8 & 6.6 & 4 \\
\hline Sep & '24-30 & 2018 & 39 & 30.4 & 22.0 & 91.3 & 69.7 & 80.6 & 1 & 4.6 & 5.4 & 3.1 \\
\hline Oct & '01-07 & 2018 & 40 & 32.6 & 18.5 & 84.3 & 60.1 & 0 & 0 & 9.1 & 4.6 & 4 \\
\hline Oct & '08-14 & 2018 & 41 & 30.9 & 17.1 & 82.7 & 61.4 & 2.6 & 0 & 7.3 & 4.7 & 3.5 \\
\hline Oct & ' $15-21$ & 2018 & 42 & 30.7 & 14.3 & 86.9 & 59.1 & 0 & 0 & 7.8 & 3.5 & 3.3 \\
\hline Oct & '22-28 & 2018 & 43 & 29.6 & 12.0 & 90.4 & 50.7 & 0 & 0 & 8.3 & 3.4 & 3.1 \\
\hline Oct-Nov & '29-04 & 2018 & 44 & 29.9 & 13.7 & 87.7 & 54.3 & 4.2 & 1 & 7.1 & 3.2 & 2.7 \\
\hline Nov & '05-11 & 2018 & 45 & 27.5 & 11.7 & 93.9 & 54.0 & 0 & 0 & 7.7 & 2.8 & 2.4 \\
\hline Nov & ' $12-18$ & 2018 & 46 & 26.5 & 11.8 & 93.3 & 63.1 & 0 & 0 & 6.5 & 2.3 & 2.2 \\
\hline Nov & '19-25 & 2018 & 47 & 26.3 & 10.5 & 93.4 & 54.3 & 0 & 0 & 7.7 & 1.8 & 2.6 \\
\hline
\end{tabular}


Table.2 Standard Meteorological Week' average weather data from May, 2019 to November, 2019 recorded at G. B. Pant University of Agriculture and Technology

\begin{tabular}{|c|c|c|c|c|c|c|c|c|c|c|c|c|}
\hline \multirow[t]{3}{*}{ Month } & \multirow[t]{3}{*}{ Date } & \multirow[t]{3}{*}{ Year } & \multirow{3}{*}{$\begin{array}{c}\text { Metero } \\
\text { Week No. } \\
\text { (2018) }\end{array}$} & \multicolumn{2}{|c|}{ Temperature $\left({ }^{\circ} \mathbf{C}\right)$} & \multirow{2}{*}{\multicolumn{2}{|c|}{$\begin{array}{c}\text { Relative humidity } \\
(\%)\end{array}$}} & \multirow{3}{*}{$\begin{array}{c}\text { Rainfall } \\
\text { (mm) }\end{array}$} & \multirow{3}{*}{$\begin{array}{c}\text { Number } \\
\text { of rainy } \\
\text { days }\end{array}$} & \multirow{3}{*}{$\begin{array}{c}\text { Sunshine } \\
\left(\text { hours day }^{-1}\right)\end{array}$} & \multirow{3}{*}{$\begin{array}{c}\text { Wind } \\
\text { Velocity } \\
\left(\mathbf{K m ~ h r}^{-1}\right)\end{array}$} & \multirow{3}{*}{$\begin{array}{c}\text { Evaporation } \\
\left(\mathrm{mm} \mathrm{day}^{-1}\right)\end{array}$} \\
\hline & & & & \multirow[t]{2}{*}{ Maximum } & \multirow[t]{2}{*}{ Minimum } & & & & & & & \\
\hline & & & & & & $712 \mathrm{am}$ & $\begin{array}{l}1412 \\
\text { pm }\end{array}$ & & & & & \\
\hline May-Jun & '28-03 & 2019 & 22 & 40.1 & 23.0 & 50.1 & 28.3 & 0 & 0 & 9.8 & 8.7 & 11.1 \\
\hline Jun & '04-10 & 2019 & 23 & 38.9 & 26.0 & 63.4 & 37.0 & 23.4 & 1 & 10 & 6.9 & 10.1 \\
\hline Jun & ‘11-17 & 2019 & 24 & 39.0 & 25.1 & 69.3 & 36.4 & 18.4 & 1 & 9.4 & 8.6 & 10.9 \\
\hline Jun & '18-24 & 2019 & 25 & 35.9 & 24.2 & 76.6 & 52.1 & 62.2 & 2 & 8.2 & 7 & 7.2 \\
\hline Jun-Jul & '25-01 & 2019 & 26 & 34.6 & 25.6 & 76.9 & 54.4 & 153 & 1 & 8.5 & 5 & 7.2 \\
\hline Jul & ‘02-08 & 2019 & 27 & 33.9 & 26.1 & 79.1 & 68.6 & 30.8 & 3 & 4.7 & 4.7 & 5.2 \\
\hline Jul & ‘09-15 & 2019 & 28 & 31.0 & 25.3 & 94.6 & 75.6 & 144.9 & 5 & 1.5 & 5 & 4.2 \\
\hline Jul & '16-22 & 2019 & 29 & 32.7 & 25.7 & 84.3 & 64.3 & 41.2 & 1 & 5.4 & 3 & 4.2 \\
\hline Jul & ' $23-29$ & 2019 & 30 & 32.4 & 26.5 & 84.9 & 71.0 & 16.8 & 3 & 3.8 & 6.7 & 4.6 \\
\hline Jul-Aug & '30-05 & 2019 & 31 & 33.3 & 26.0 & 88.1 & 67.4 & 108.2 & 4 & 4.8 & 5 & 4.9 \\
\hline Aug & '06-12 & 2019 & 32 & 32.7 & 25.8 & 88.1 & 70.1 & 116.5 & 3 & 5.1 & 3.8 & 4.7 \\
\hline Aug & '13-19 & 2019 & 33 & 32.0 & 25.4 & 89.3 & 74.1 & 51.2 & 4 & 5.2 & 5.8 & 4.8 \\
\hline Aug & ‘20-26 & 2019 & 34 & 32.3 & 24.7 & 89.9 & 65.6 & 37.8 & 1 & 5.3 & 2.4 & 4.1 \\
\hline Aug-Sep & '27-02 & 2019 & 35 & 33.8 & 25.7 & 85.6 & 66.1 & 174.6 & 2 & 6.1 & 1.9 & 4.5 \\
\hline Sep & '03-09 & 2019 & 36 & 33.1 & 25.3 & 90.0 & 72.0 & 112.2 & 2 & 5.8 & 3.5 & 4.3 \\
\hline Sep & '10-16 & 2019 & 37 & 33.1 & 25.7 & 89.4 & 69.9 & 7.8 & 1 & 5.5 & 3.5 & 4.3 \\
\hline Sep & ' $17-23$ & 2019 & 38 & 32.1 & 22.4 & 88.1 & 62.4 & 14.2 & 2 & 7 & 4.5 & 3.6 \\
\hline Sep & ' $24-30$ & 2019 & 39 & 30.9 & 23.0 & 88.0 & 65.1 & 6.2 & 1 & 6.1 & 1.8 & 3.6 \\
\hline Oct & '01-07 & 2019 & 40 & 30.9 & 21.3 & 92.3 & 57.3 & 0 & 0 & 7.6 & 1.9 & 2.9 \\
\hline Oct & '08-14 & 2019 & 41 & 31.9 & 18.8 & 88.1 & 47.3 & 0 & 0 & 8.6 & 2.4 & 3.2 \\
\hline Oct & '15-21 & 2019 & 42 & 31.0 & 18.0 & 85.7 & 49.6 & 0 & 0 & 6 & 1.2 & 2.7 \\
\hline Oct & '22-28 & 2019 & 43 & 29.6 & 16.2 & 91.9 & 46.7 & 0 & 0 & 6.5 & 2.2 & 2.8 \\
\hline Oct-Nov & '29-04 & 2019 & 44 & 29.2 & 17.1 & 89.4 & 57.1 & 0 & 0 & 1.2 & 2.4 & 2 \\
\hline Nov & '05-11 & 2019 & 45 & 29.1 & 14.0 & 85.3 & 43.7 & 0 & 0 & 6 & 2.7 & 2.4 \\
\hline Nov & '12-18 & 2019 & 46 & 29.0 & 13.3 & 91.4 & 44.3 & 0 & 0 & 6.6 & 3.2 & 2.2 \\
\hline Nov & ' $19-25$ & 2019 & 47 & 25.0 & 11.5 & 94.0 & 47.3 & $\mathbf{0}$ & 0 & 4.7 & 1.8 & 2.1 \\
\hline
\end{tabular}


Table.3 Amount of nutrient supplied through various sources

\begin{tabular}{|c|c|c|c|c|c|}
\hline S. No. & Particulars & $\begin{array}{c}\text { Application } \\
\text { Rate }\end{array}$ & $\mathbf{N}\left(\mathbf{K g ~ h a}^{-\mathbf{1}}\right)$ & $\mathbf{P}\left(\mathbf{K g ~ h a}^{-\mathbf{1}}\right)$ & $\mathbf{K}\left(\mathbf{K g ~ h a}^{\mathbf{- 1}}\right)$ \\
\hline $\mathbf{1 .}$ & $100 \%$ RDF (NPK Mix) & $150 \mathrm{~kg} \mathrm{ha}^{-1}$ & 18 & 48 & 16 \\
\hline $\mathbf{2 .}$ & $100 \%$ Vermicompost & $5 \mathrm{t} \mathrm{ha}^{-1}$ & 95 & 55 & 75 \\
\hline $\mathbf{3 .}$ & $50 \%$ RDF (NPK Mix) & $75 \mathrm{~kg} \mathrm{ha}^{-1}$ & 9 & 24 & 8 \\
\hline $\mathbf{4 .}$ & $50 \%$ Vermicompost & $2.5 \mathrm{t} \mathrm{ha}^{-1}$ & 47.5 & 27.5 & 37.5 \\
\hline
\end{tabular}

Table.4 Plant height and leaf area, dry matter production of pigeonpea at 30 and 60 DAS stages as influenced by various planting methods and nutrient management practices

\begin{tabular}{|c|c|c|c|c|c|c|c|c|}
\hline \multirow[t]{3}{*}{ Treatments } & \multicolumn{4}{|c|}{ Plant height (cm) } & & & & \\
\hline & \multicolumn{2}{|c|}{30 DAS } & \multicolumn{2}{|c|}{60 DAS } & \multicolumn{2}{|l|}{30 DAS } & \multicolumn{2}{|c|}{60 DAS } \\
\hline & 2018 & 2019 & 2018 & 2019 & 2018 & 2019 & 2018 & 2019 \\
\hline \multicolumn{9}{|c|}{ Factor A: Planting Method and Geometry } \\
\hline$C_{1}-$ Conventional Sowing $60 \mathrm{~cm} \times 20 \mathrm{~cm}$ & 36.7 & 40.7 & 105.6 & 113.6 & 1914 & 2008 & 2812 & 3232 \\
\hline$T_{1}$ - Transplanting $60 \mathrm{~cm} \times 20 \mathrm{~cm}$ & 30.4 & 32.9 & 124.1 & 144.8 & 1628 & 1719 & 3032 & 3332 \\
\hline$T_{2}$ - Transplanting $90 \mathrm{~cm} \times 40 \mathrm{~cm}$ & 30.2 & 32.7 & 113.9 & 135.0 & 1528 & 1585 & 9520 & 10780 \\
\hline$T_{3}$ - Transplanting $90 \mathrm{~cm} \times 60 \mathrm{~cm}$ & 30.1 & 32.6 & 105.5 & 112.1 & 1483 & 1458 & 14814 & 17244 \\
\hline SEm \pm & 1.0 & 1.0 & 3.8 & 7.2 & 79 & 61 & 257 & 330 \\
\hline $\mathrm{CD}(\mathrm{P}=\mathbf{0 . 0 5})$ & 3.4 & 3.6 & 13.3 & 24.9 & 277 & 214 & 891 & 1140 \\
\hline \multicolumn{9}{|l|}{ Factor B: Nutrient Management } \\
\hline $\begin{array}{c}\mathrm{N}_{1^{-}} 100 \% \text { RDF (18 kg N: } 48 \mathrm{~kg} \mathrm{P}_{2} \mathrm{O}_{5}: 24 \\
\left.\operatorname{kg~K}_{2} \mathrm{O} \mathrm{ha}^{-1}\right)\end{array}$ & 31.6 & 34.5 & 99.3 & 112.4 & 1430 & 1511 & 7164 & 8266 \\
\hline $\mathrm{N}_{2}$ - Vermicompost at 5 ton $\mathrm{ha}^{-1}$ & 31.9 & 34.8 & 113.4 & 126.6 & 1631 & 1651 & 7495 & 8598 \\
\hline $\begin{array}{c}\mathrm{N}_{3^{-}}-50 \% \mathrm{RDF}+\text { Vermicompost at } 2.5 \\
\text { ton } \text { ha }^{-1}\end{array}$ & 32.1 & 35.1 & 123.5 & 140.1 & 1853 & 1914 & 7974 & 9076 \\
\hline SEm \pm & 0.5 & 0.5 & 3.5 & 4.8 & 136 & 40 & 216 & 169 \\
\hline $\mathrm{CD}(\mathrm{P}=\mathbf{0 . 0 5})$ & NS & NS & 10.49 & 14.26 & 398 & 118 & 630 & 491 \\
\hline
\end{tabular}

Table.5 Days to 50 per cent flowering and maturity of pigeonpea as influenced by various planting methods and nutrient management practices

\begin{tabular}{|c|c|c|c|c|}
\hline \multirow[t]{2}{*}{ Treatments } & \multicolumn{2}{|c|}{$\begin{array}{c}\text { Days to } 50 \text { per cent } \\
\text { flowering }\end{array}$} & \multicolumn{2}{|c|}{ Days to maturity } \\
\hline & 2018 & 2019 & 2018 & 2019 \\
\hline \multicolumn{5}{|l|}{ Factor A: Planting Method and Geometry } \\
\hline $\mathrm{C}_{1^{-}}$Conventional Sowing $60 \mathrm{~cm} \times 20 \mathrm{~cm}$ & 79 & 80 & 158 & 159 \\
\hline$T_{1^{-}}$Transplanting $60 \mathrm{~cm} \times 20 \mathrm{~cm}$ & 89 & 89 & 173 & 176 \\
\hline$T_{2^{-}}$Transplanting $90 \mathrm{~cm} \times 40 \mathrm{~cm}$ & 88 & 87 & 172 & 175 \\
\hline$T_{3^{-}}$Transplanting $90 \mathrm{~cm} \times 60 \mathrm{~cm}$ & 86 & 86 & 167 & 170 \\
\hline SEm \pm & 1.1 & 1.6 & 0.85 & 1.3 \\
\hline $\mathrm{CD}(\mathbf{P}=\mathbf{0 . 0 5})$ & 4.1 & 5.6 & 2.9 & 4.8 \\
\hline \multicolumn{5}{|l|}{ Factor B: Nutrient Management } \\
\hline$N_{1^{-}} 100 \%$ RDF (18 kg N: $\left.48 \mathrm{~kg} \mathrm{P}_{2} \mathrm{O}_{5}: 24 \mathrm{~kg} \mathrm{~K}_{2} \mathrm{Oha}^{-1}\right)$ & 87 & 87 & 170 & 172 \\
\hline $\mathrm{N}_{2}$ - Vermicompost at 5 ton $\mathrm{ha}^{-1}$ & 84 & 84 & 166 & 168 \\
\hline $\mathrm{N}_{3^{-}}-50 \% \mathrm{RDF}+$ Vermicompost at 2.5 ton $\mathrm{ha}^{-1}$ & 85 & 86 & 168 & 170 \\
\hline SEm \pm & 0.5 & 0.8 & 1.4 & 1.0 \\
\hline $\mathrm{CD}(\mathrm{P}=\mathbf{0 . 0 5})$ & 1.4 & 2.4 & 4.1 & 2.9 \\
\hline
\end{tabular}


Table.6 Grain yield, stalk yield, stick yield and biological yield and harvest index of pigeonpea as influenced by various planting methods and nutrient management practices

\begin{tabular}{|c|c|c|c|c|}
\hline \multirow[t]{2}{*}{ Treatments } & \multicolumn{2}{|c|}{ Grain Yield $\left(\mathrm{kg} \mathrm{ha}^{-1}\right)$} & \multicolumn{2}{|c|}{ Gross Returns } \\
\hline & 2018 & 2019 & 2018 & 2019 \\
\hline \multicolumn{5}{|l|}{ Factor A: Planting Method and Geometry } \\
\hline $\mathrm{C}_{1}$ - Conventional Sowing $60 \mathrm{~cm} \times 20 \mathrm{~cm}$ & 1865 & 2010 & $1,05,832$ & $1,16,567$ \\
\hline$T_{1}$ - Transplanting $60 \mathrm{~cm} \times 20 \mathrm{~cm}$ & 2106 & 2234 & $1,19,541$ & $1,29,566$ \\
\hline$T_{2^{-}}$Transplanting $90 \mathrm{~cm} \times 40 \mathrm{~cm}$ & 2475 & 2707 & $1,40,431$ & $\mathbf{1 , 5 7 , 0 0 0}$ \\
\hline$T_{3}$ - Transplanting $90 \mathrm{~cm} \times 60 \mathrm{~cm}$ & 2279 & 2493 & $1,29,358$ & $1,44,613$ \\
\hline SEm \pm & 72 & 109 & 4137 & 6374 \\
\hline $\mathrm{CD}(\mathrm{P}=\mathbf{0 . 0 5})$ & 252 & 380 & 14317 & 22057 \\
\hline \multicolumn{5}{|l|}{ Factor B: Nutrient Management } \\
\hline $\begin{array}{l}\mathrm{N}_{1^{-}} 100 \% \text { RDF (18 kg N: } 48 \mathrm{~kg} \mathrm{P}_{2} \mathrm{O}_{5}: 24 \\
\left.\mathrm{~kg} \mathrm{~K}_{2} \mathrm{O} \mathrm{ha}^{-1}\right)\end{array}$ & 2032 & 2216 & $1,15,321$ & $1,28,538$ \\
\hline $\mathrm{N}_{2^{-}}$Vermicompost at 5 ton $\mathrm{ha}^{-1}$ & 2193 & 2382 & $1,24,453$ & $\mathbf{1 , 3 8 , 1 2 7}$ \\
\hline $\begin{array}{l}\mathrm{N}_{3^{-}} 50 \% \mathrm{RDF}+\text { Vermicompost at } 2.5 \text { ton } \\
\mathrm{ha}^{-1}\end{array}$ & 2319 & 2485 & $1,31,599$ & $1,44,145$ \\
\hline SEm \pm & 63 & 55 & 3587 & 3203 \\
\hline $\mathrm{CD}(\mathrm{P}=0.05)$ & 184 & 161 & 10470 & 9350 \\
\hline
\end{tabular}

Fig.1 Microbial content in soil as influenced by various planting methods and nutrient management practices in pigeonpea crop

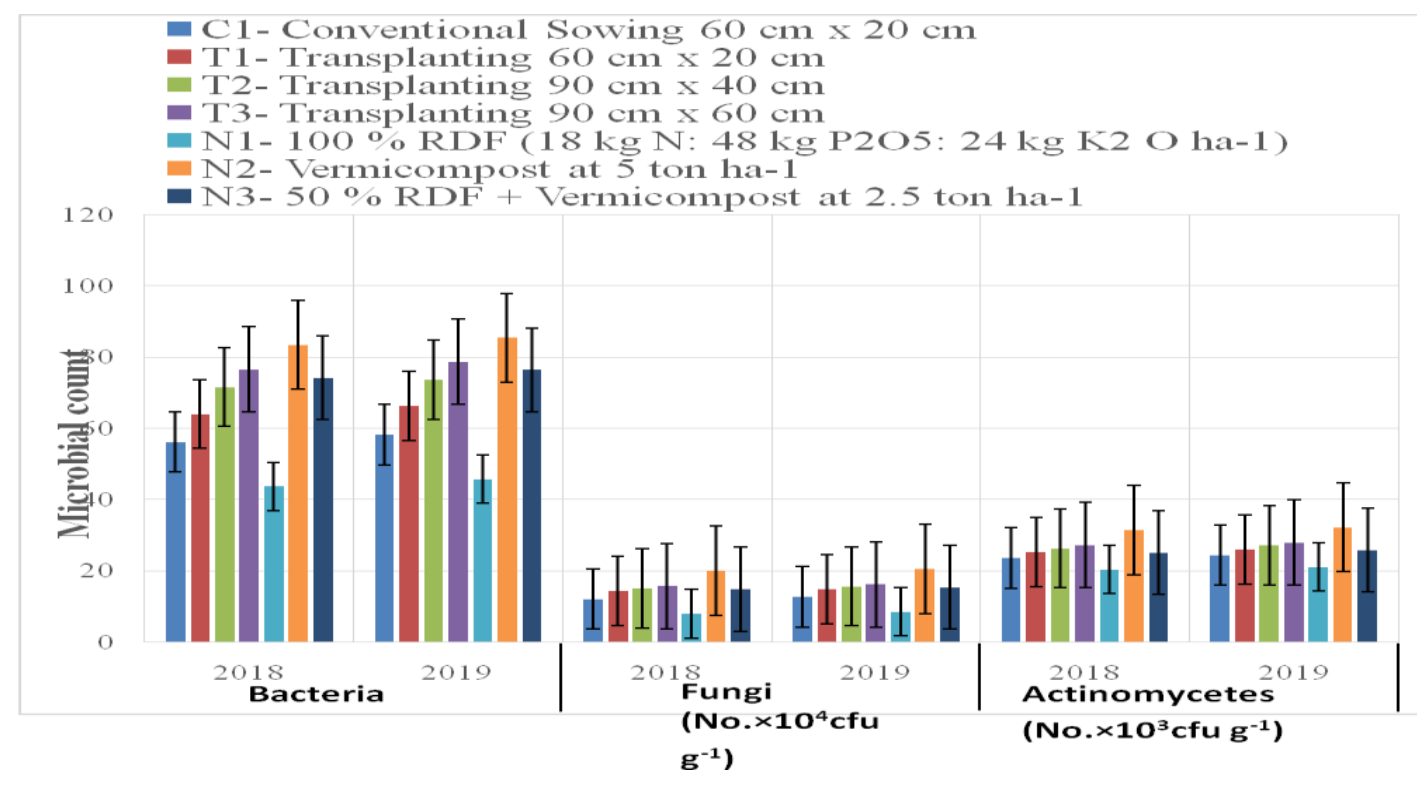


The population of microorganisms in vermicompost is higher than traditional composts and the type of microbes found depends on the types of earthworm species used for composting. The common growth enhancing microbes found are as follows, Pseudomonas oxalaticus, Rhizobium japonicum, Oseudomonas putida, NPK availability enhancers viz., Azospirillum sp., Azotobacter sp., Nitrosomonas sp., Nitrobacter sp. and phosphate solubulisers (Gopal et al., 2009; Pathama and Sakthivel, 2012).

\section{Effect on grain yield}

The grain yield was affected significantly during both the years, both by planting systems and nutrient management practices. Transplanting of pigeon-pea at $90 \times 40 \mathrm{~cm}$ produced significantly highest grain yield during both the years being $2475 \mathrm{~kg} / \mathrm{ha}$ in 2018 and $2707 \mathrm{~kg} / \mathrm{ha}$ in 2019. Transplanting at $90 \times 60 \mathrm{~cm}$ recorded the next higher grain yield being 7.924 and $7.91 \%$ lower, respectively in 2018 and 2019. The grain yield did not vary significantly between transplanting at $90 \times 60 \mathrm{~cm}$ and $90 \times 40 \mathrm{~cm}$ during both the years. Conventional sowing registered significantly lowest grain yield during both the years.

The reduction was $12.9,22.1 \& 32.7 \%$ in 2018 and 11.1, 24.1 \& $34.6 \%$ in 2019, respectively against $60 \times 20 \mathrm{~cm}, 90 \times 60 \mathrm{~cm}$ and $90 \times 40 \mathrm{~cm}$, transplanting systems. Nutrient management practice of 50\% RDF + VC @ $2.5 \mathrm{t} /$ ha obtained the maximum grain yield $(2319 \mathrm{~kg} / \mathrm{ha}$ in 2018 and $2485 \mathrm{~kg} / \mathrm{ha}$ in 2019) which was found to be at par with $\mathrm{N}_{2}$ (2193 kg/ha in 2018 and $2382 \mathrm{~kg} / \mathrm{ha}$ in 2019) during both the years. In the first year, $\mathrm{N}_{2}$ and $\mathrm{N}_{1}$ did not differ significantly for grain yield, while during second year, $\mathrm{N}_{2}(2382 \mathrm{~kg} / \mathrm{ha})$ recorded significantly higher grain yield than $\mathrm{N}_{1}(2216 \mathrm{~kg} / \mathrm{ha})$. The increase in grain yield with $\mathrm{N}_{2}$ and $\mathrm{N}_{3}$ over $\mathrm{N}_{1}$ was $\mathrm{xx}$ and $\mathrm{xx} \%$ in 2018 and $\mathrm{xx}$ and $\mathrm{xx} \%$ during 2019.

Yield is the product of plant population per unit area and the single plant yield. Maximum yield can be obtained at the optimum density where competition between the plants is minimum by making better utilization of available space, light, moisture and nutrients more efficiently. Therefore transplanting at 90 x $40 \mathrm{~cm}$ gave better yields even though per plant yield is higher in transplanting at $90 \mathrm{x}$ $60 \mathrm{~cm}$. This planting geometry resulted in higher dry matter production and its accumulation in leaves, stem and pods owing to higher plant population than the widest spacing. Similar findings were also reported by Pavan et al., (2009), Poornima et al., (2009), Potdar et al., (2010), Anilkumar et al., (2011), Jamadar and Sajjan (2014), Mallikarjun (2012), Murali et al., (2014), Singh and Kirar (2016) and Panda et al., (2017). In integrated nutrient application the higher yield might be due to the cumulative effect of elevated growth stature as well as yield attributes under the condition of adequate nutrient supply, favouring the production of photosynthates coupled with better partitioning to the sink. Further application of vermicompost might have enhanced the activity of dehydrogenase, phosphatase and urease in the soil. Hence, the positive effect of combined application of vermicompost with RDF was reflected with higher grain and stalk yields. Pandey and Khuswaha (2009), Saritha et al, (2012), Kumawat et al., (2013), Pandey et al., (2013), Hajari et al., (2015), Pal et al., (2016), Somashekar (2017) and Sajjan (2018) also postulated similar views.

\section{Effect on gross returns}

The gross returns recorded were highest for transplanting at $90 \times 40 \mathrm{~cm}$ which was followed by transplanting at 90x60 $\mathrm{cm}$ and 
was statistically at par with the same. Significantly lower gross returns were recorded for transplanting at $60 \times 20 \mathrm{~cm}$ and conventional planting systems which didn't vary significantly from each other during both of the experimental years. The nutrient management practices affected gross returns significantly. The combined application of $50 \%$ RDF + VC@ 2.5 t / ha recorded highest gross returns and was at par with $\mathrm{N}_{2}$ i.e., VC (a) $5 \mathrm{t} / \mathrm{ha}$ which was the next better treatment. The lowest gross returns were recorded for $\mathrm{N}_{1}$. However, $\mathrm{N}_{1}$ was on par with $\mathrm{N}_{2}$ statistically in both the years. Similar results were perceived by Gholve et al., (2005), Patil et al., (2007), Pandey et al., (2013), Singh (2016) and Somashekar (2017).

The highest gross apprehended with transplanting at wider spacing and integrated usage of $50 \%$ RDF + vermicompost @ 2.5 t/ha might be due to the higher grain and stalk yields as well as lesser production costs in comparison to transplanting at closer spacing. The lowest gross returns were noticed to be conventional planting system due to the lowest grain and stalk yield. Similar results were perceived by Malik (2009), Poornima et al., (2010), Goud and Andhalkar (2012), Priyanka et al., (2013) and Singh and Kirar (2016).

Thus it can be concluded that Thus for sustained productivity of pigeon pea, it can be transplanted at $90 \times 40 \mathrm{~cm}$ spacing and for nutrient application integration of $50 \% \mathrm{RDF}+$ Vermicompost at 2.5 ton ha $^{-1}$ could be taken as the most promising practices for System of Pigeonpea Intensification for higher yield, economics of pigeonpea along with maintenance of soil quality and fertility for the sustenance of soil ecology. Transplanting in many crops has advantage over direct seeding with respect to crop growth and yield. It is more true in rainfed farming areas of northern Karnataka, as the rainfall is not only scanty but also erratic. Thus, timely sowing and also soil moisture during different stages of crop growth becomes the most limiting factor in pigeonpea production. In order to ensure timely sowing and higher yields of System of Pigeonpea Intensification is one of the best agronomic management. The integration of organics and inorganics not onlyprovides better nutrients both macro and micro for longer period substantially but also enhances soil physico-chemico-biological properties. It's the better solution to the need of the hour i.e. intensifying pigeonpea yield.

\section{Authors' Contributions}

The work was carried out in collaboration with all authors. Author SSM carried out the entire experiment, recorded the observations regularly, performed the statistical analysis, wrote the protocol as well as the first draft of the manuscript. Author CB, AS, VKS and $\mathrm{NP}$ acted as the advisor and co-advisors in carrying out the experiment assisting SSM in design of experiment, clearing the doubts, providing all the guidance required for smooth conduction of the experiment. All the coauthors along with SSM managed the literature searches and recorded feedback as well as guided SSM in finalization of the manuscript by editing the same. All the authors read and approved the final manuscript.

\section{References}

Anilkumar, S. N., Pujari, B. T., Vishwanatha, S., Kopalkar, B. G., Desai, B. K. and Veeresh, 2011. Influence of different methods of establishment on the growth characters of pigeonpea (Cajanus cajan L.) during kharif season, Res. J. Agric. Sci., 2(2): 234-236.

Anonymous, 2015. Area, production, and average yield, Directorate of Economics and Statistics, Department of Agriculture and Cooperation report, New Delhi, available on the website: http:// www.agricoop.nic.in, p. 12.

Barthwal, A. 2013. Integrated nutrient management in pigeonpea based intercropping system. Ph.D. (Agronomy) Thesis, Govind Ballabh 
Pant University of Agriculture and Technology, Pantnagar, Uttarakhand (India).

Bhatt, M. 2017. Impact of long-term balanced and imbalanced use of fertilizers on soil quality and productivity in rice-wheat cropping system. Ph.D. (Soil Science) Thesis, Govind Ballabh Pant University of Agriculture and Technology, Pantnagar, Uttarakhand (India).

Bhanu kumar, M., Hulihalli, U. K., Arvind Kumar, B. N. and Meena, M. K. 2011. Effect of fertility and planting geometry on growth and yield of medium duration pigeonpea hybrid ICPH-2671. Res. J. Agric. Sci., 2(3): 715-718.

Chaudhary, S. K. and Thakur, S. K., 2005. Productivity of pigeonpea (Cajanus cajan) based intercrops. Indian Journal of Agricultural Sciences, 75(8): 496497.

Gholve, S. G., Shinde, S. G. and Gaikwad, C. B. 2005. Efficacy of integrated nutrient management for pigeonpea-pearlmillet intercropping system under dryland conditions. J. Maharashtra. Agric. Univ., 30(1): 41-43.

Gomez, K.A. and Gomez, A. A.1984. Statistical procedure for Agriculture for Agriculture Research. A WilleyInterscience Publication, John Willey and Sons. New York, Pp. 108-137.

Gopal M, Gupta A, Sunil E, Thomas VG, 2009. Amplification of plant beneficial microbial communities during conversion of coconut leaf substrate to vermicompost by Eudrilus sp. Current Microbiology. 59:15-20.

Goud, V. V. and Andhalkar, A. S., 2012. Feasibility studies in transplanted pigeonpea + soybean intercropping system. Journal of Food and Legumes. 25(2): 128-130.

Hajari, R. V., Patel, S. D., Sonani, V. V., Mahida, A. K. and Chavadhari, R. L. 2015. Varietal response of pigeonpea to organic manures under rainfed condition. Bioinfolet. 12(4 b): 927 930.

Jamadar, M. I. and Sajjan, A. S., 2014. Effect of transplanting on yield and quality of pigeonpea [Cajanus cajan (L.) Millsp.].Bioinfolet, 11(2A): 319-322.

Kumawat, N., Singh, R. P., Kumar, R. and Hari, O. 2013. Effect of integrated nutrient management on the performance of sole and intercropped pigeonpea (Cajanus cajan) under rainfed conditions. Indian J. Agron., 58(3): 309-315.

Mallikarjun, C. 2012. Performance of hybrid pigeonpea [Cajanus cajan (1.) millsp.] (cv. icph-2671) under different planting methods and geometry in northern dry zone of karnataka. M. Sc. (Agri.) Thesis, Univ. Agric. Sci., Dharwad, Karnataka (India).

Ministry of Agriculture and Cooperation. 2018. Agricultural Statistics at a Glance, agricoop.nic.in.

Orozco SH, Cegarra J, Trujillo LM, Roig A. 1996. Vermicomposting of coffee pulp using the earthworm Eisenia foetida: effects on $\mathrm{C}$ and $\mathrm{N}$ contents and the availability of nutrients. Biology and Fertility of Soils. 22: 162-166

Pal, A. K., Singh, R. S., Shukla, U. N. and Singh, S. 2016. Growth and production potential of pigeonpea (Cajanus cajan L.) as influenced by intercropping and integrated nutrient management. Journal of Applied and Natural Science, 8(1): $179-183$.

Panda, P. K., Mohapatra, P. M., Kar, A., Bal, S. S. and Mishra, I.O.P., 2017. Effect of genotype, method of planting and Intrarow spacing on yield and exonomics of peripheral pigeon pea in Odisha. Indian Agriculturist. 61 (3 \& 4): 151-155.

Pandey, I. B., Singh, S. K. and Tiwari, S. 2013. Integrated nutrient management for sustaining the productivity of 
pigeonpea (Cajanus cajana) based intercropping systems under rainfed condition. Indian J. Agron., 58(2): 192197.

Pandey, R. and Khuswaha, H. S. 2009. Productivity and profitability of pigeonpea under different sources of nutrients in rainfed conditions of central India. Journal of Food and Legumes. 22(4): 303-304.

Parameswari, K., Vanangamudi, K. and Kavitha, S. 2003. Effect of spacing on hybrid seed yield of pigeonpea hybrid CoPH2. Madras Agric. J. 90 (10-12): 691-696.

Pathma J and Sakthivel N. 2012. Microbial diversity of vermicompost bacteria that exhibit useful agricultural traits and waste management potential. Springer Plus. 1(1):1-19.

Patil, A. B., and Padmani, D. R. 2007. Effect of INM practices on yield, quality and economics of Pigeonpea (Cajanus cajan L. Millsp.) under rainfed conditions. Internat. J. Agric. Sci., 1.3(2): 202-204.

Pavan, A. S., Nagalikar, V. P., Halepyati, A. S. and Pujari, B. T., 2009. Effect of planting on the yield, yield components and economics of transplanted pigeonpea. Karnataka Journal of Agricultural Sciences. 22(2): 433-434

Poornima, D. S., 2009. Studies on feasibility of transplanting pigeonpea in sole cropping and finger millet based intercropping system. M. Sc. (Agri.) Thesis, Univ. Agric. Sci., Bangalore, Karnataka (India).

Potdar, M. P., Chittapur, B. M., Salakinkoppa, S. R., Sharma, A. and Dharmraj, P. S., 2010. Response of transplanted pigeonpea (Cajanus cajan L.) to planting geometry under rainfed conditions of north eastern dry zone of Karnataka, In: National Symposium on Resource Management Approaches towards Livelihood Security, December
2-4, Bangalore, Karnataka, p. 8.

Pradeep, S, Ullasa, M Y, Naik, A K K, Ganapathi and Divya, M. (2018).Effect of different organic nutrient management practices on growth, yield of Pigeon pea (Cajanus cajan L. Millsp.) and soil properties. Research Journal of Agricultural Sciences.9 (2): 352-357.

Praharaj, C. S., Kumar, N., Singh, U., Singh, S. S. and Singh, J., 2015. Transplanting in pigeonpea - A contingency measure for realizing higher productivity in Eastern Plains of India. Journal of Food and Legumes. 28(1): 34-39.

Priyanka, K., Patil, S. S., Hiremath, G. M., Joshi, A. T. and Kulkarni, S. A. 2013. Comparative analysis of transplanted and dibbled method of redgram cultivation in Bidar district of Karnataka. Karnataka Journal of Agricultural Sciences. 26(2): 238-242.

Ramesh, P., Singh, M., Panwar, N. R., Singh, A. B. and Ramana, S. 2006. Response of pigeonpea (Cajanus cajan) varities to organic manures and their influence on fertility and enzyme activity of soil. Indian Journal of Agricultural Sciences. 76 (4): 252-254.

Reddy, A. S. R., Babu, R., Reddy, M. C. S., Khan, M. M. and Rao, M. M. 2011. Integrated nutrient management in pigeonpea (Cajanus cajana). Int. J. Applied Bio. Pharm. Tech. 2(2): 476470.

Sajjan, A.S. 2018. Response of red gram cultivars to transplanting and planting geometry under rainfed conditions of Northern dry zone of Karnataka. Indian Journal of Agric. Res. 52(5): 518-523.

Salakinkoppa, S.R. and Patil, H.Y. 2010. Enhancing the productivity of pigeonpea by transplanting technique in command area. National symposium on "Food Security in Context of Changing Climate" held at Kanpur during October 
30 to November 012010. pp. 133.

Saritha, K.S., Pujari, B.T., Basavarajappa, R, Naik, M.K., Ramesh Babu and Desai,B.K. 2012. Growth and productivity as influenced by nutrient management practices on pigeon pea in upland alfisols of Tripura.Saarc Journal of Agriculture. 26(2): 238-242.

Saxena, K.B., Kumar, R.V. and Sultana, R. 2010. Quality nutrition through pigeonpea a review. Crop Science. 2 (11): 1335-1344.

Singh, R.K. and B.S. Kirar. 2016. Yield maximization of pigeonpea through innovative technology of system of pigeonpea intensification- A success story. Innovative Farming, 1(4): 179182.

Somashekar, T.N, 2017. Evaluation of soil physico-chemical properties, growth and yield of pigeonpea as influenced by method of planting and integrated nutrient management in vertisols of karnataka M.Sc., (Agri.) Thesis, University of Agricultural Sciences, Dharwad, Karnataka, India.

Sujatha, H.T, 2017. Crop Diversification And Intensification For Higher Productivity And Profitability In Transplanted Pigeonpea. M.Sc., (Agri.) Thesis, Indira Gandhi Krishi Vishwavidyalaya, Raipur, Chattishgarh, India.

Tamboli, B.D., Patil, Y.M., Bhakare, B.D., Kadu, P.P, Somawanshi, R.B., Sonar, K.R. and Patil, M.D. 1995. Fertilizer recommendations based on soil test for targeted yield of pigeon pea. Journal of Maharashtra Agriculture University. 20 (3): 327-329.

\section{How to cite this article:}

Sweta Shikta Mahapatra, Chandra Bhushan, Anil Shukla, V. K. Singh and Navneet Pareek. 2020. Feasibility and Possibility of Transplanted Pigeonpea (Cajanus cajan L.) under Different Spacing and Nutrient Management Practices. Int.J.Curr.Microbiol.App.Sci. 9(12): 3053-3067. doi: https://doi.org/10.20546/ijcmas.2020.912.362 